\title{
APPLICATION OF AGRICULTURAL GYPSUM ASSOCIATED WITH NITROGEN FERTILIZATION: AN APPROACH TO THE NUTRITIONAL STATUS IN PASTURE AND SOIL
}

\author{
João Vitor Rodrigues Padovan ${ }^{1}$, Lucas Aparecido Manzani Lisboa ${ }^{1,2}$, Gabriel Banos Rodrigues ${ }^{1}$, João \\ Leonardo Miranda Bellotte ${ }^{3}$, Eduardo Leal Oliveira Camargo ${ }^{3}$, Alan dos Santos Cardoso ${ }^{1}$, Hiago Augusto \\ Amaral Sacco ${ }^{1}$
}

\begin{abstract}
:
Brazilian soil presents serious problems with plant production, due to its low fertility and high acidity content, besides that the toxicity caused by the chemical element aluminum. To overcome these problems, agricultural gypsum is used to neutralize the action of aluminum and, together with the assistance of nitrogen sources, ensures greater forage productivity. The objective of this work was to recover a pasture area with the application of agricultural gypsum associated with nitrogen fertilization. The experimental design was in randomized blocks with four replications, in a $2 \times 4$ factorial scheme with $50 \mathrm{~kg} \mathrm{ha}^{-1}$ of $\mathrm{N}$ in the form of ammonium nitrate and $50 \mathrm{~kg} \mathrm{ha}^{-1}$ of $\mathrm{N}$ in the form of urea, plus four doses of agricultural plaster, of which: $0 ; 750 ; 1500$ and $3000 \mathrm{~kg} \mathrm{ha}^{-1}$ in pasture installed in Urochloa humidicola. The dose of $1884 \mathrm{~kg} \mathrm{ha}^{-1} \mathrm{of}$ gypsum provided the highest concentration of calcium when applied in conjunction with ammonium nitrate. For sulfur, a linear response was observed, regardless of the nitrogen source used. The use of urea significantly increased the nitrogen levels in the leaves. The application of gypsum, regardless of the nitrogen source, provided a linear response in the calcium and sulfur levels in the leaves.
\end{abstract}

Keywords: Chemical attributes of the soil; Plant nutrition; Forage; Urochloa humidicola.

\section{APLICAÇÃO DE GESSO AGRÍCOLA ASSOCIADO À ADUBAÇÃO NITROGENADA: UMA ABORDAGEM NO ESTADO NUTRICIONAL NA PASTAGEM E SOLO}

\section{RESUMO:}

O solo brasileiro apresenta sérios problemas com a produção vegetal, devido à sua baixa fertilidade e alto teor de acidez, além da toxicidade provocada pelo elemento químico alumínio. Para superar esses problemas, é usado o gesso agrícola para neutralizar a ação do alumínio e juntamente com o aporte de fontes de nitrogênio, garante maior produtividade forrageira. $\mathrm{O}$ objetivo deste trabalho foi de recuperar uma área de pastagem com a aplicação de gesso agrícola associado à adubação nitrogenada. $O$ delineamento experimental foi em blocos casualizados com quatro repetições, em esquema fatorial $2 \times 4$ com $50 \mathrm{~kg} \mathrm{ha}^{-1} \mathrm{de}$ $\mathrm{N}$ na forma de nitrato de amônio e $50 \mathrm{~kg} \mathrm{ha}^{-1} \mathrm{de} \mathrm{N}$ na forma de ureia, além de quatro doses de gesso agrícola, sendo: 0; 750; 1500 e $3000 \mathrm{~kg} \mathrm{ha}^{-1} \mathrm{em}$ pastagem instalada em Urochloa humidicola. A dose de $1884 \mathrm{~kg} \mathrm{ha}^{-1}$ de gesso proporcionou a maior concentração de cálcio quando aplicada em conjunto com nitrato de amônio.

\footnotetext{
${ }^{1}$ Educational Fundation of Andradina (FEA), Andradina, São Paulo, Brazil. *e-mail: lucas@ @ea.br

${ }^{2}$ São Paulo State University (Unesp), College of Technology and Agricultural Sciences, Dracena, São Paulo, Brazil.

${ }^{3}$ Eldorado Brasil Celulose Plants Nursery
} 
Para o enxofre, foi observada uma resposta linear, independentemente da fonte de nitrogênio utilizada. O uso de ureia aumentou significativamente os níveis de nitrogênio nas folhas. A aplicação de gesso, independentemente da fonte de nitrogênio, proporcionou resposta linear nos níveis de cálcio e enxofre nas folhas.

Palavras-chave: Atributos químicos do solo; Nutrição de plantas; Forragem; Urochloa humidicola. 


\section{INTRODUCTION}

The Brazilian agricultural territory is basically use for pasture for livestock, with the Urochloa genus occupying a wide area in several management systems, with approximately 170 million hectares (Pezzopane et al., 2015). The cultivars of Urochloa spp. have shown prominence in extensive production systems, as they are plants that are not very demanding to climatic conditions and are characterized as essential food support in livestock breeding, have adaptability to medium and high fertility soils, pest rusticity, good production and dry matter quality and high response to fertilization (Silva et al., 2016; Germano et al., 2018).

In contrast, the majority of Brazilian soils destined for plant production have problems with nutrient contents unavailable in the arable layer of the soil, with low fertility and toxicity caused by $\mathrm{Al}$ (aluminum), which include minimizing crop yields. In the case of pastures, the high concentration of aluminum acts directly on the physiological and metabolic processes of the crop, negatively influence the absorption of water and nutrients, resulting in a reduction of the root system, and consequent reduction of the shoot (Yamamoto et al., 2018).

Therefore, it is necessary to search alternatives to improve the chemical properties of the soil in depth, enabling the permanence and success in the development of pasture. Gypsum can be an alternative to alleviate these problems, as it is considered a soil conditioner, where its use reduces Al activity and increases base saturation in subsurface layers, enabling good plant development and greater exploration of the soil by the roots (Backes et al., 2018).

Nitrogen in turn is considered one of the essential nutrients for the growth and quality of pastures (Costa et al., 2016), as it participates in the synthesis of organic compounds, such as amino sugars, amines, amides, vitamins, pigments, amino acids, nucleic acids and chlorophyll, which in turn, provides greater development of tillers and leaves
(Heinrichs et al., 2013). Studies with nitrogen fertilization at a dose of $100 \mathrm{~kg} \mathrm{ha}^{-1}$ showed an increase in dry matter productivity and leaf chlorophyll indexes, in Mombaça grass in northwest São Paulo (Galindo et al., 2018).

Nitrogen fertilization can be a resource that allows increasing the indications for the production of forages, among nitrogen fertilizers, urea and ammonium nitrate are the most used, because they obtain affordable prices and high solubility in the fraction of the soil, however high temperatures, humidity relatively low, minimum amounts of precipitation and soil characteristics favor, through hydrolysis, losses by nitrogen volatilization. The availability of nitrogen is one of the factors that control the plant's growth and development processes, guaranteeing an increase in its production. In a survey, live calves weight gain ha- ${ }^{-1}$ increased when doses of $150 \mathrm{~kg}$ of $\mathrm{N} \mathrm{ha}^{-1}$ were applied to oat pasture (Lupatini et al., 2013).

This work aims to understand the effects caused by the application of agricultural gypsum associated with nitrogen fertilization: an approach on the nutritional status of plants on soil fertility.

\section{MATERIAL AND METHODS}

\section{Location}

The experiment was carried out in January 2018 in a pasture area of Urochloa humidicola at the Veterinary Hospital of FEA - Educational Fundation of Andradina, located in the Andradina city, State of São Paulo, located at Longitude 20 ${ }^{\circ}$ 1'14.397" South and Latitude 51 20 '59.424" West and at 388 meters altitude.

\section{Climate}

The local climate, according to the Koppen classification, is of the Aw type, characterized by the seasons of hot weather in summer and dry winter, between November and March there is the highest rainfall. The annual averages temperature, precipitation and relative humidity are, respectively, 
$30^{\circ} \mathrm{C}$ of maximum, $19^{\circ} \mathrm{C}$ of minimum, accumulated rainfall of $1311 \mathrm{~mm}$ and average humidity of $78 \%$.

\section{Soil description}

The area's soil was classified according to Embrapa (2013) as hypopherric oxissol. The chemical analysis was carried out in the laboratory of the Ilha Solteira Faculty Engineering, of a soil sample collected at a depth of $0-20 \mathrm{~cm}$ where the following chemical attributes were determined: $\mathrm{P}, \mathrm{K}$, $\mathrm{Ca}$, and $\mathrm{Mg}$ the ion exchange resin method, $\mathrm{pH}$ in $\mathrm{CaCl}_{2}$, was used; organic matter by calorimetry; $\mathrm{H}+\mathrm{Al}$ with SMP buffer solution; $\mathrm{Al}$ in $\mathrm{KCl}$ (Raij et al. 2001). As shown in Table 1.

Table 1 - Soil Chemical attributes at the beginning of the experiment. Andradina, 2019.

\begin{tabular}{|c|c|c|c|c|c|c|c|c|c|c|c|}
\hline $\mathrm{pH}$ & $\mathrm{OM}$ & $\mathrm{P}$ & $\mathrm{K}$ & $\mathrm{Ca}$ & $\mathrm{Mg}$ & $\mathrm{H}+\mathrm{Al}$ & $\mathrm{Al}$ & SB & CEC & V\% & $\mathrm{m} \%$ \\
\hline $\mathrm{CaCl}_{2}$ & $\mathrm{~g} \mathrm{dm}^{-3}$ & $\mathrm{mg} \mathrm{dm}^{-3}$ & ---- & & & $----n$ & & & & ----- & \\
\hline 4.6 & 13 & 7.0 & 1.8 & 10 & 6.0 & 22 & 2.0 & 17.8 & 39.8 & 45 & 10 \\
\hline
\end{tabular}

OM: Organic matter; SB: Sum of bases; CEC: Cation exchange capacity; V\%: Base saturation; m\%: Saturation by aluminum.

\section{Experimental design and treatments}

The experimental design was randomized blocks in a $3 \times 4$ factorial arrangement, that is, absence of nitrogen, $50 \mathrm{~kg} \mathrm{ha}{ }^{-1}$ in the form of ammonium nitrate and $50 \mathrm{~kg} \mathrm{ha}^{-1}$ urea, interacting with four doses of agricultural gypsum, namely: 0 ; $750 ; 1500$ and $3000 \mathrm{~kg} \mathrm{ha}^{-1}$ and with four replications, totaling 48 plots.

The plots were $16.0 \mathrm{~m}^{2}(4.0 \mathrm{~m} \times 4.0 \mathrm{~m})$, adopting a $0.5 \mathrm{~m}$ border on each side, making a useful area of $9.0 \mathrm{~m}^{2}$ and a distance equivalent to $1.0 \mathrm{~m}$ between blocks and parcels. The supply of phosphorus and potassium was uniform in all treatments according to Raij et al. (1996).

\section{Soil chemical attributes}

120 days after the application of the treatments, chemical analyzes were carried out in the laboratory of the Ilha Solteira Faculty Engineering, of soil samples collected at a depth of $0-20 \mathrm{~cm}$ where the following chemical attributes were determined: $\mathrm{Ca}$ using the ion exchange resin method and $\mathrm{S}_{-} \mathrm{SO}_{4}{ }^{2-}$ by extraction with calcium phosphate solution according to Raij et al. (2001).

\section{Analysis of the plants nutritional status}

Laboratory analyzes were performed to determine the $\mathrm{N}$ levels (crude protein), $\mathrm{P}, \mathrm{K}, \mathrm{Ca}, \mathrm{Mg}$ and S according to Malavolta et al. (1997) in the aerial part of the forage at 120 days after planting.

\section{Statistical analysis}

All variables were subjected to the $F$ test $(p$ $<0.05)$ and regression analysis was applied to the gypsum doses, where their linear and quadratic models were tested. To determine the best nitrogen source, the Tukey test was applied at a 5\% probability of the event occurring. The point of maximum technical efficiency (PMTE) was obtained through the first order derivative of the quadratic regression equation between the doses where the mathematical model was employed $y=-b / 2 c$ (Banzatto and Kronka, 2013). The statistical program was used RStudio (R, 2015).

\section{RESULTS AND DISCUSSIONS}

As for sulfur, the different nitrogen sources did not show a significant difference, as shown in Table 2. It's important to emphasize that there was no interaction between the factors studied.

The application of ammonium nitrate caused an increase in the $\mathrm{Ca}$ content in the soil by $27 \%$ compared to the application of urea (Figure 1). For the attributes of soil fertility, the present work observed that the application of ammonium nitrate 
significantly increased the $\mathrm{Ca}$ content in the soil compared to the application of urea. This increase in calcium will favor the fertility built in the soil profile, ensuring better sustainability and productivity of pasture (Lopes and Guimarães, 2016). By studying a clayey red yellow latosol from the cerrado, Lacerda et al. (2015) proved that the construction of soil fertility will enable the fertilizer dosages to be reduced by up to $25 \%$, providing a gradual increase in the final crop production.

In relation to the calcium levels in the soil, the use of ammonium nitrate responded in a quadratic way to the application of gypsum, with a maximum point of $1,884 \mathrm{~kg} \mathrm{~h}^{-1}$ as of gypsum, and urea showed a linear response, (Figure 2).

Table 2 - Analysis of variance of $\mathrm{N}$ sources and regression of agricultural gypsum doses, where the linear, quadratic and cubic models of $\mathrm{Ca}$ and $\mathrm{S}_{-} \mathrm{SO}_{4}{ }^{2-}$ of the soil were tested at 120 days after the beginning of the experiment. Andradina, 2019.

\begin{tabular}{llll}
\hline $\begin{array}{l}\text { Nitrogen source }(\mathrm{N}) \\
\mathrm{p} \text { value }\end{array}$ & $\mathrm{Ca}$ & $\mathrm{S}_{-\mathrm{SO}_{4}{ }^{2-}}$ \\
$\mathrm{CV} \%$ & & $0.0247^{*}$ & $0.5960 \mathrm{Ns}$ \\
\hline $\mathrm{OA}$ & & 36.40 & 39.05 \\
\hline Gypsum doses $(\mathrm{G})$ & & 10.15 & 15.93 \\
Ammonium nitrate & Doses & $\mathrm{p}$ value of regressions \\
& Regression & $0.0355^{*}$ & $0.0001^{* *}$ \\
\hline Urea & $\mathrm{Q}$ & $\mathrm{L}$ \\
\hline $\mathrm{p}$ value de $\mathrm{NxG}$ & Doses & $0.0183^{*}$ & $0.0012^{* *}$ \\
\hline
\end{tabular}

CV: Coefficient of variation. OA: Overall average. NA $=$ Ammonium nitrate and $U=$ Urea. Ns $p=0.05 ; * 0.01=<p<0.05 ; * * p$ $<0.01$. FV: Variation factor. L: Polynomial of the 1st degree. Q: Polynomial of the 2nd degree.

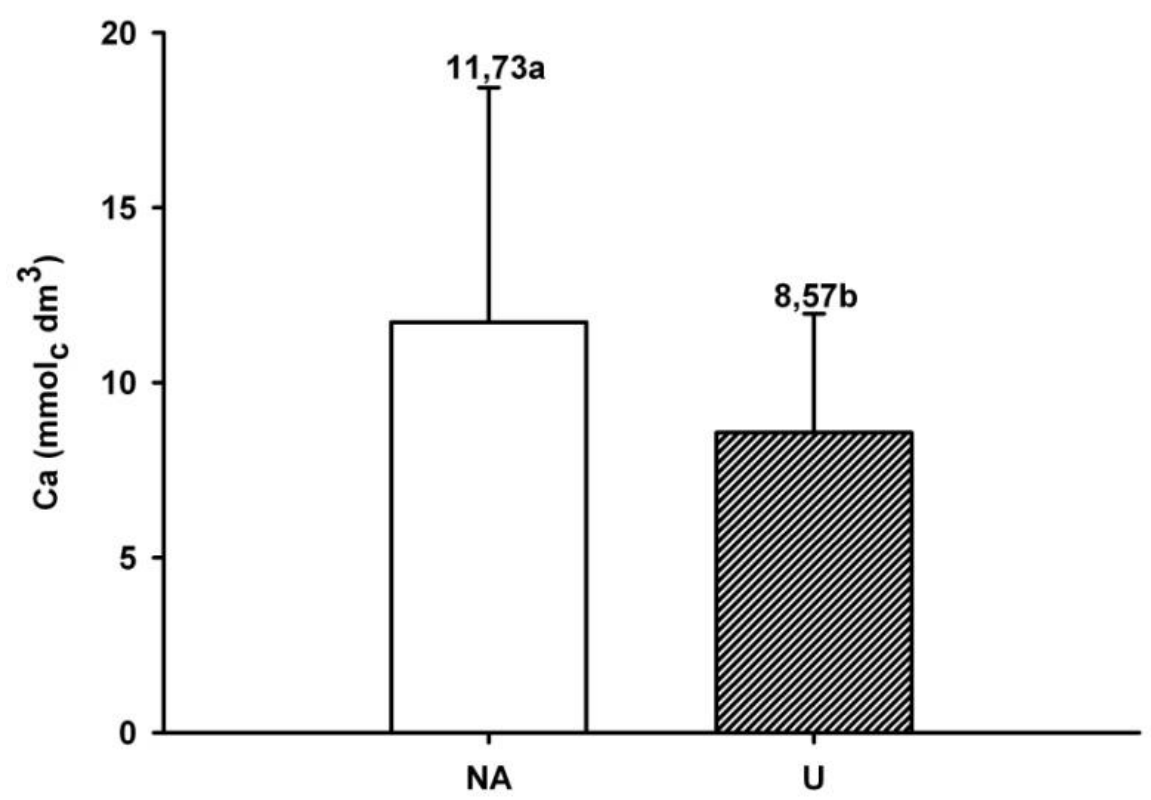

Figure 1. Average values of $\mathrm{Ca}$ in the soil after the use of two sources of N. Andradina, 2019. NA = Ammonium nitrate; $U=$ Urea. The means followed by the same letter do not differ statistically. The Tukey test was applied at the level of 5\% probability. 


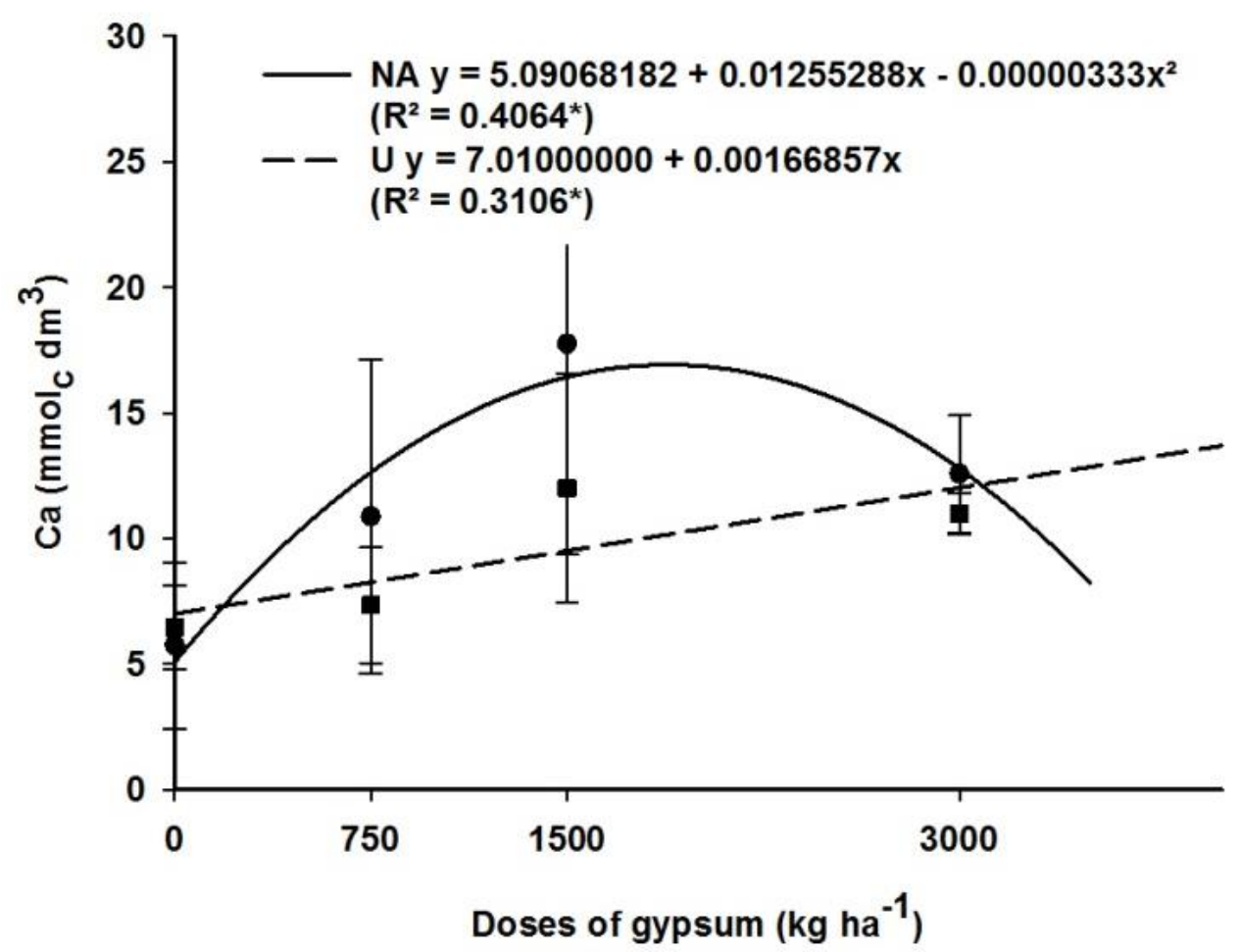

Figure 2. Regressions of the nutrient $\mathrm{Ca}$ in the soil as a function of $\mathrm{N}$ sources and with the application of agricultural gypsum. Andradina, 2019. $\mathrm{NA}=$ Ammonium Nitrate and $\mathrm{U}=$ Urea. Ns $\mathrm{p}=0.05 ; * 0.01=<\mathrm{p}$ $<0.05 ; * * \mathrm{p}<0.01$.

The increase in calcium content in the soil with the application of gypsum is caused by the chemical reaction of calcium sulfate in the soil, acting in the calcium supply, as well as facilitating the carrying of exchangeable bases in subsurface (Malavolta, 1981). Related research finds that when testing different doses of agricultural gypsum in a typical dystrophic Red-Yellow Latosol, the application of $9,340 \mathrm{~kg} \mathrm{ha}^{-1}$ of the corrective material provided a considerable increase in the $\mathrm{Ca}$ content in the subsurface, consequently increasing the productivity of the studied grass by $39 \%$ (Pauletti et al., 2014). Such characteristics of $\mathrm{Ca}$ mobility in the soil are related to the use of gypsum. This reaction is due to the effect of $\mathrm{SO}_{4}{ }^{2-}$ in blocking the charge of $\mathrm{Ca}^{2+}$, which leads to the formation of an ionic pair between these two ions, thus preventing $\mathrm{Ca}^{2+}$ from binding to soil charges, facilitating its descent to deeper layers, which characterizes this concealed as a sub-surface conditioner (Nava et al., 2012).

Regarding the sulfur levels in the soil, the nitrogen sources did not differ from each other, according to Table 2. The application of gypsum increased linearly to the sulfur levels in the soil, as shown in Figure 3.

The increase in gypsum doses caused an increase in sulfur levels due to the release of the nutrient in the soil solution, caused by dissolution of calcium sulfate. Such aspects may be closely related to the fact that the gypsum increases the size and the porosity between soil aggregates, since it acts as a supplier of cations that act in the neutralization of the loads, which may potentiate this phenomenon, due to the increase in the $\mathrm{pH}$ of the soil. Soil and the concentration of the exchangeable bases of $\mathrm{Ca}^{2+}$ and $\mathrm{Mg}^{2+}$ ions in the soil solution (Nogueira et al., 2016).

Doses of 0 to $2,820 \mathrm{~kg}$ of gypsum per ha ${ }^{-1}$, in $U$. decumbens intercropped with Stylosanthes guianensis cv. Mineirão, caused the sulfur concentrations in subsurface to increase (Mesquita et al., 2004). Thus, the benefits of applying gypsum on the availability of $S$ in soil fertility become relevant in studies related to grasses. The use of gypsum in a dystrophic Red Latosol, significantly increased of $\mathrm{Ca}^{2+}$ and $\mathrm{S}_{-} \mathrm{SO}_{4}{ }^{2-}$ levels (Caires et al., 2004). Other researchers also proved that applying up to $1,200 \mathrm{~kg}$ 
$\mathrm{ha}^{-1}$ of gypsum in Red Latosol caused higher levels of absorption of the nutrient $\mathrm{S}_{-} \mathrm{SO}_{4}{ }^{2-}$ in subsurface (Caires et al., 2011).

For the attributes of plant nutrition, it was observed that the application of urea caused a significant increase in the nitrogen content in the leaf, according to Table 3.

The observed averages of nitrogen in the leaves demonstrate that urea presented $13.2 \%$ more of this nutrient as shown in Figure 4. This significant increase may be associated with the form of forages assimilating urea, this is due to the metabolic processes that are related to $\mathrm{C} 4$ plants (Taiz et al., 2017). A study carried out in order to compare three sources of nitrogen: urea, ammonium nitrate and ammonium sulfate, proved that the use of urea was more efficient in absorbing the nutrient in grasses (Merigout et al., 2008). Recent studies have obtained superior responses to the application of urea compared to ammonium nitrate when evaluating the nitrogen increase in plants in the development of a grass (Sousa et al., 2016).

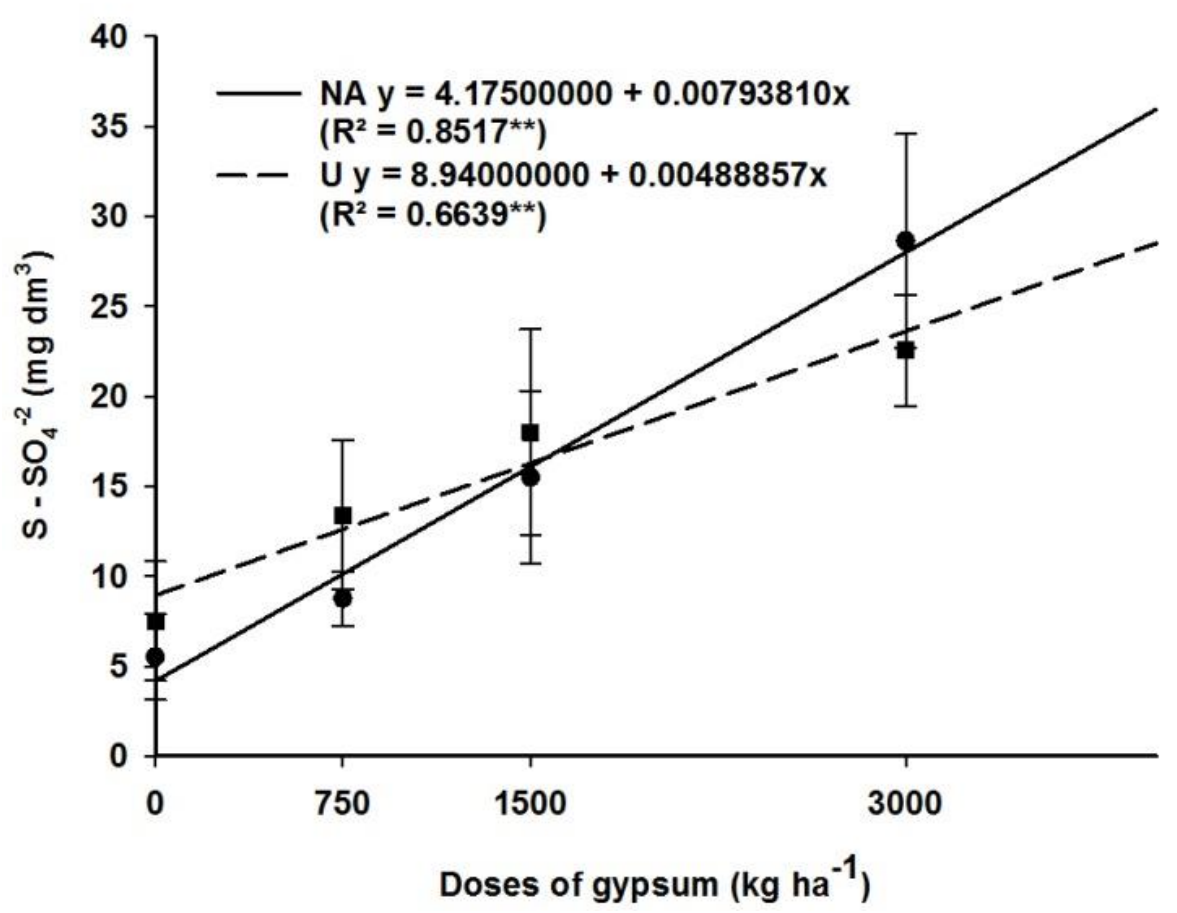

Figure 3. Regressions of the nutrient $\mathrm{S}_{-} \mathrm{SO}_{4}{ }^{2-}$ in the soil as a function of $\mathrm{N}$ sources and with the application of agricultural gypsum. Andradina, 2019. NA = Ammonium Nitrate and $U=$ Urea. Ns $p=0.05 ; * 0.01=<p$ $<0.05 ; * * \mathrm{p}<0.01$.

Figure 5 shows Pearson's correlations between the variables analyzed in $U$. humidicola after the use of gypsum associated with two sources of nitrogen.

The positive correlations between $\mathrm{NxP}$ nutrients are notorious; $\mathrm{MgxP}$ and $\mathrm{MgxCa}$, while negative correlations were also observed between
CaxK and MgxK as shown in Table 4. This proves that some nutrients when present in greater concentration or even their deficiency in the tissues of the vegetable can inhibit the presence of others, as it is necessary to preserve a nutritional balance to maintain all metabolic processes. 
Table 3 - Analysis of variance of $\mathrm{N}$ sources and regressions of agricultural gypsum doses, where the linear, quadratic and cubic models of $\mathrm{N}$ nutrients were tested; P; K; Here; $\mathrm{Mg}$ and $\mathrm{S}$ in U. humidicola at 120 days after the beginning of the experiment. Andradina, 2019.

\begin{tabular}{|c|c|c|c|c|c|c|c|}
\hline \multirow{2}{*}{\multicolumn{2}{|c|}{ Nitrogen source $(\mathbf{N})$}} & $\mathbf{N}$ & $\mathbf{P}$ & $\mathbf{K}$ & $\mathbf{C a}$ & \multirow[t]{2}{*}{$\mathrm{Mg}$} & \multirow[t]{2}{*}{$\mathrm{S}$} \\
\hline & & \multicolumn{4}{|c|}{ 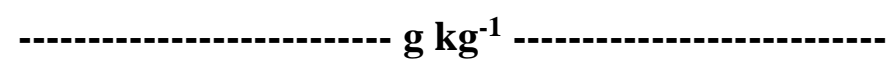 } & & \\
\hline \multicolumn{2}{|c|}{$\mathrm{p}$ value } & $0.0299 *$ & $0.5493 \mathrm{~ns}$ & $0.9020 \mathrm{Ns}$ & $0.8835 \mathrm{Ns}$ & $0.2690 \mathrm{Ns}$ & $0.8043 \mathrm{Ns}$ \\
\hline \multicolumn{2}{|c|}{$\mathrm{CV} \%$} & 15.05 & 11.91 & 15.50 & 17.18 & 20.36 & 13.76 \\
\hline \multicolumn{2}{|c|}{$\mathrm{OA}$} & 13.40 & 1.63 & 16.00 & 2.76 & 4.62 & 2.27 \\
\hline \multicolumn{2}{|c|}{$\begin{array}{l}\text { Gypsum } \\
\operatorname{doses}(G)\end{array}$} & \multicolumn{6}{|c|}{ p value of regressions } \\
\hline \multirow[t]{2}{*}{ NA } & Doses & 0.4924 & 0.4547 & 0.5532 & $0.0317 *$ & 0.3011 & $0.0014 * *$ \\
\hline & Regression & Ns & Ns & Ns & $\mathrm{L}$ & Ns & $\mathrm{L}$ \\
\hline \multirow[t]{2}{*}{$\mathrm{U}$} & Doses & 0.8541 & 0.3838 & 0.3618 & $0.0029 * *$ & 0.0453 & $0.0007 * *$ \\
\hline & Regression & Ns & Ns & Ns & $\mathrm{L}$ & Ns & $\mathrm{L}$ \\
\hline \multicolumn{2}{|c|}{$\mathrm{p}$ value of $\mathrm{NxG}$} & $0.6632 \mathrm{Ns}$ & $0.3319 \mathrm{Ns}$ & $0.7460 \mathrm{Ns}$ & $0.5576 \mathrm{Ns}$ & $0.1324 \mathrm{Ns}$ & $0.7089 \mathrm{Ns}$ \\
\hline
\end{tabular}

$\mathrm{CV}$ : Coefficient of variation. MG: Overall average. NA $=$ Ammonium nitrate and $\mathrm{U}=$ Urea. Ns $\mathrm{p}=0.05 ; * 0.01=<\mathrm{p}<0.05 ; * * \mathrm{p}$ $<0.01$. FV: Variation factor. L: Polynomial of the 1st degree. Q: Polynomial of the 2nd degree.

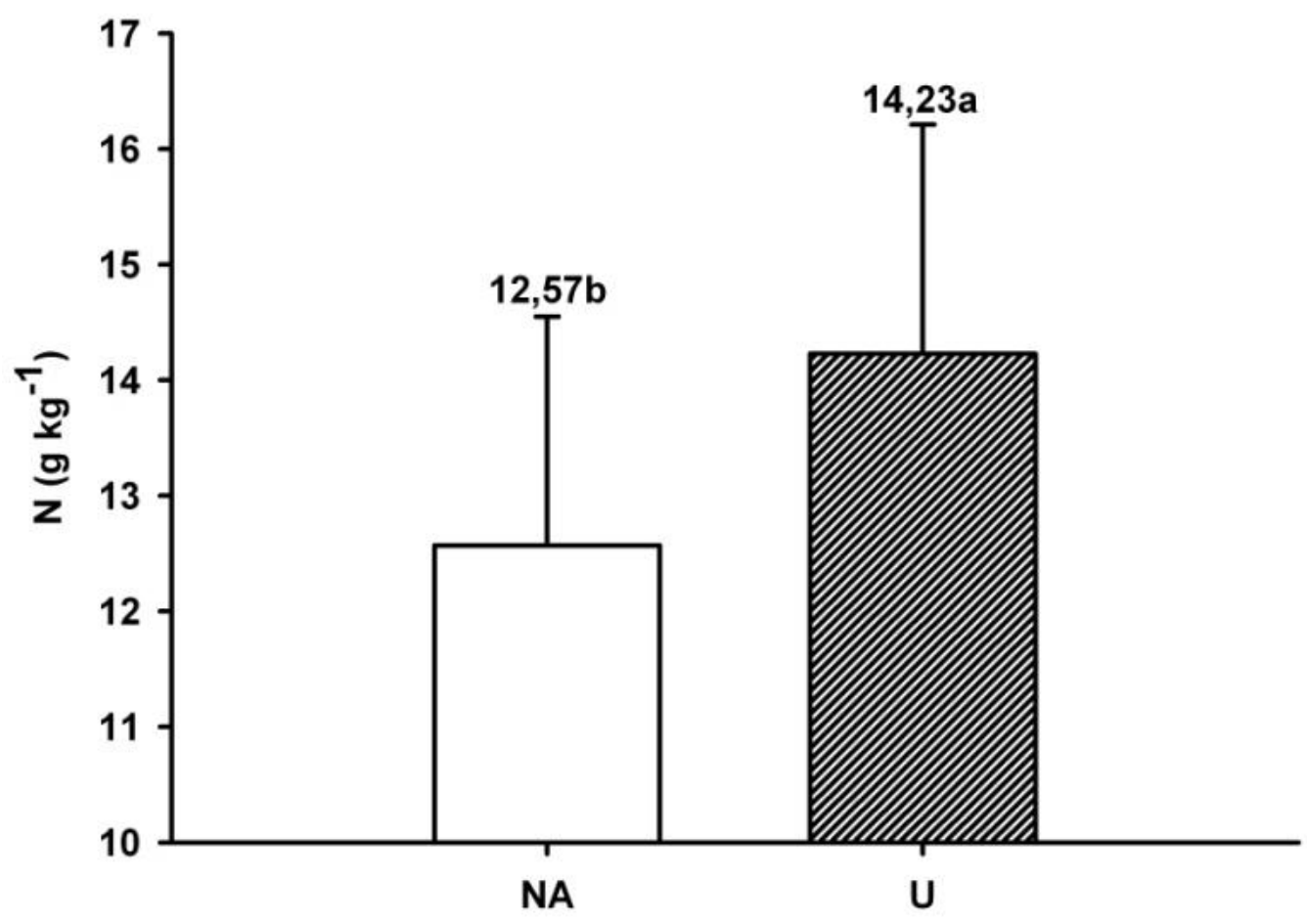

Figure 4. Average values of $\mathrm{N}$ in $U$. humidicola after using two sources of nitrogen. Andradina, 2019. NA= Ammonium nitrate; $\mathrm{U}=$ Urea.

The use of nitrogen and gypsum did not increase of the gypsum doses. The supply of cause a significant increase in the leaf contents of $\mathrm{P}$, nitrogen did not cause a significant increase in the $\mathrm{K}$ and $\mathrm{Mg}$, as shown in Figure 6.

It was observed that the content of $\mathrm{Ca}$ and $\mathrm{S}$ nutritional levels of leaves for these nutrients, as shown in Figures 7 and 8 respectively. in the leaves responded in linear ways with the 


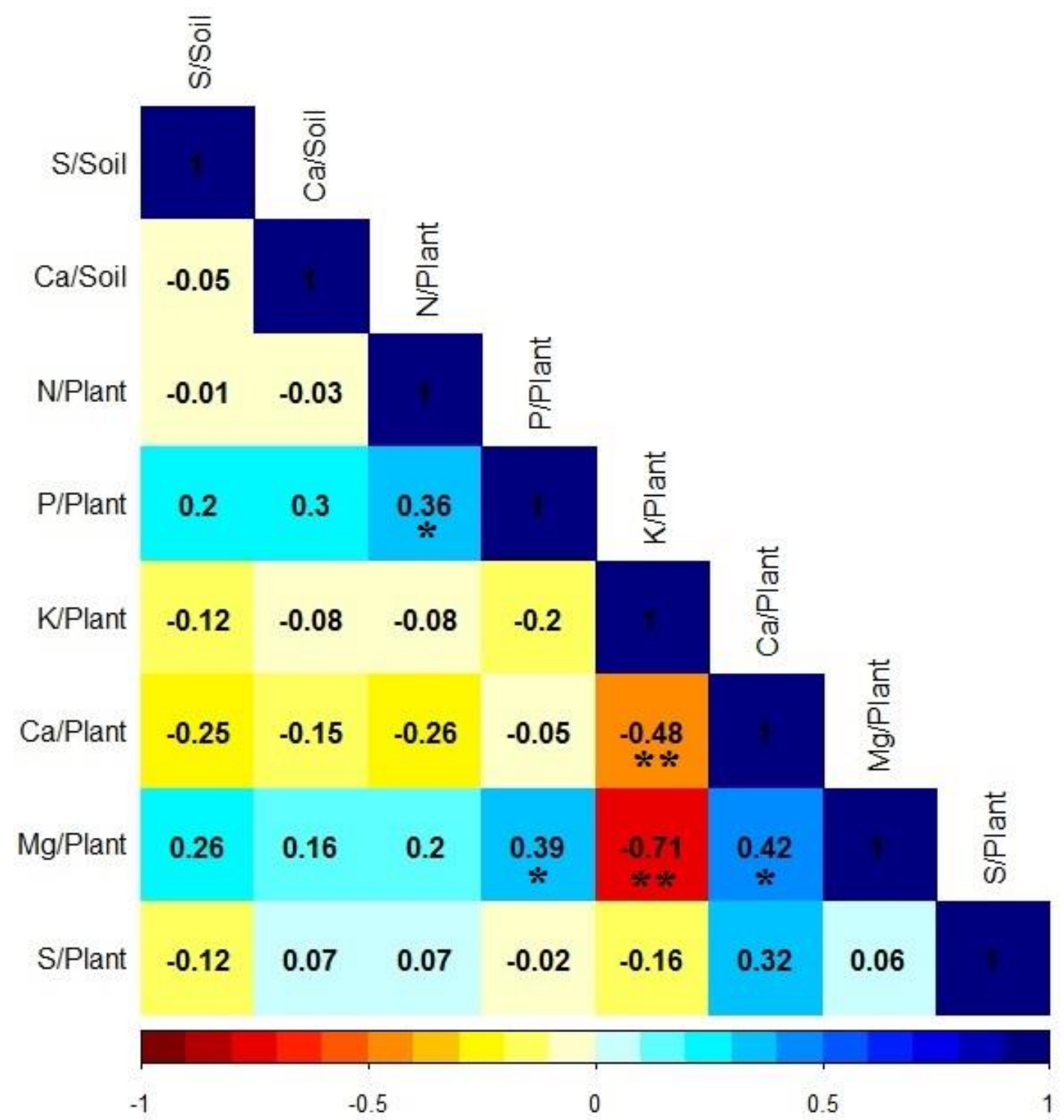

Figure 5: Pearson's correlations between the variables analyzed in $U$. humidicola after the use of gypsum associated with two sources of nitrogen. Andradina, 2019. S=Sulfur; $\mathrm{Ca}=$ Calcium; N=Nitrogen; $\mathrm{P}=$ Phosphorus; $\mathrm{K}=$ Potassium and $\mathrm{Mg}=$ Magnesium.

When comparing the export of nutrients by Marandu grass according to the application of gypsum, a survey showed that when the dose of $1,800 \mathrm{~kg}$ of gypsum was used, the average results were significant, causing an increase of $13 \%$ in the availability of $\mathrm{Ca}$ in the plants (Backes et al., 2018). Such characteristics may be related to the development of the root system provided by the application of gypsum, consequently allowing plants to use nutrients applied to the soil more efficiently (Sousa et al., 2016). In addition to making $\mathrm{Ca}$ and $\mathrm{S}$ available, the application of gypsum on the subsurface ensures an increase in the efficiency of other mobile nutrients, especially $\mathrm{N}^{-\mathrm{NO}^{3-}}$ (Cantarella and Montezano, 2010). 


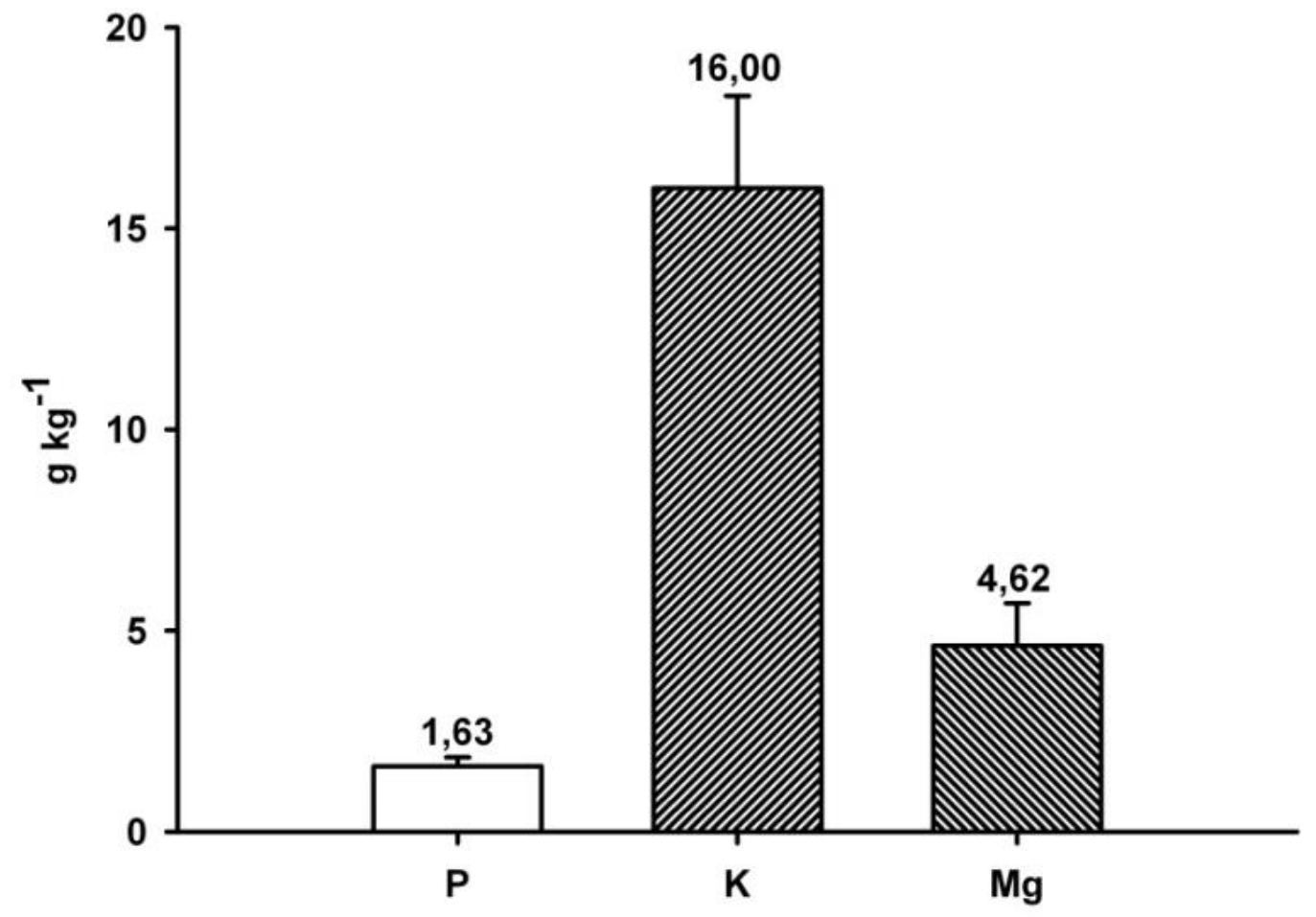

Figure 6. Average values of $\mathrm{P}$ nutrients; $\mathrm{K}$ and $\mathrm{Mg}$ in $U$. humidicola not significant due to the sources of $\mathrm{N}$ and with the application of agricultural gypsum. Andradina, 2019.

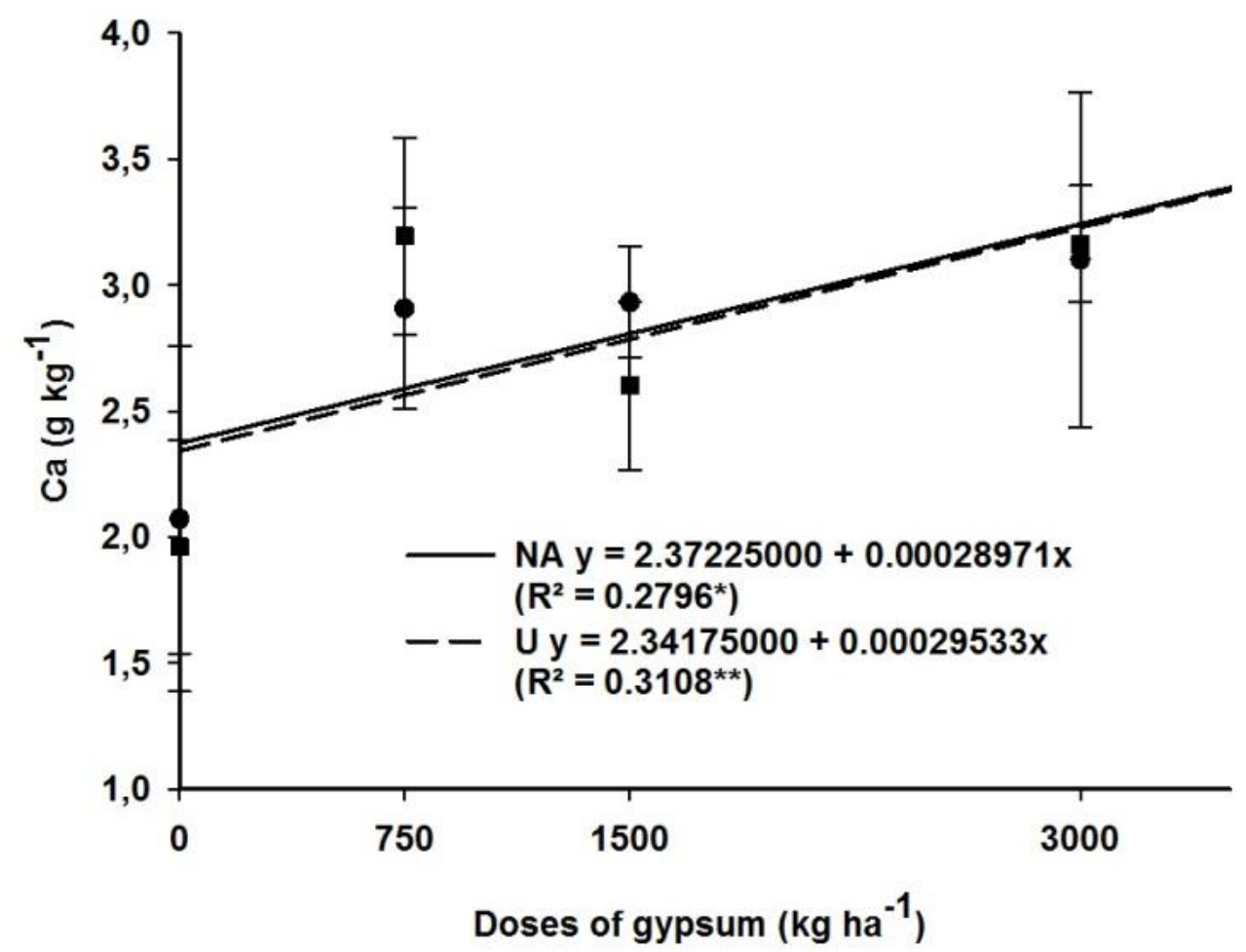

Figure 7. Regressions of the nutrient $\mathrm{Ca}$ in $U$. humidicola as a function of $\mathrm{N}$ sources and with the application of gypsum. Andradina, 2019. NA = Ammonium Nitrate and $U=$ Urea. Ns $p=0.05$; * $0.01=<\mathrm{p}<0.05 ; * * \mathrm{p}<0.01$. 


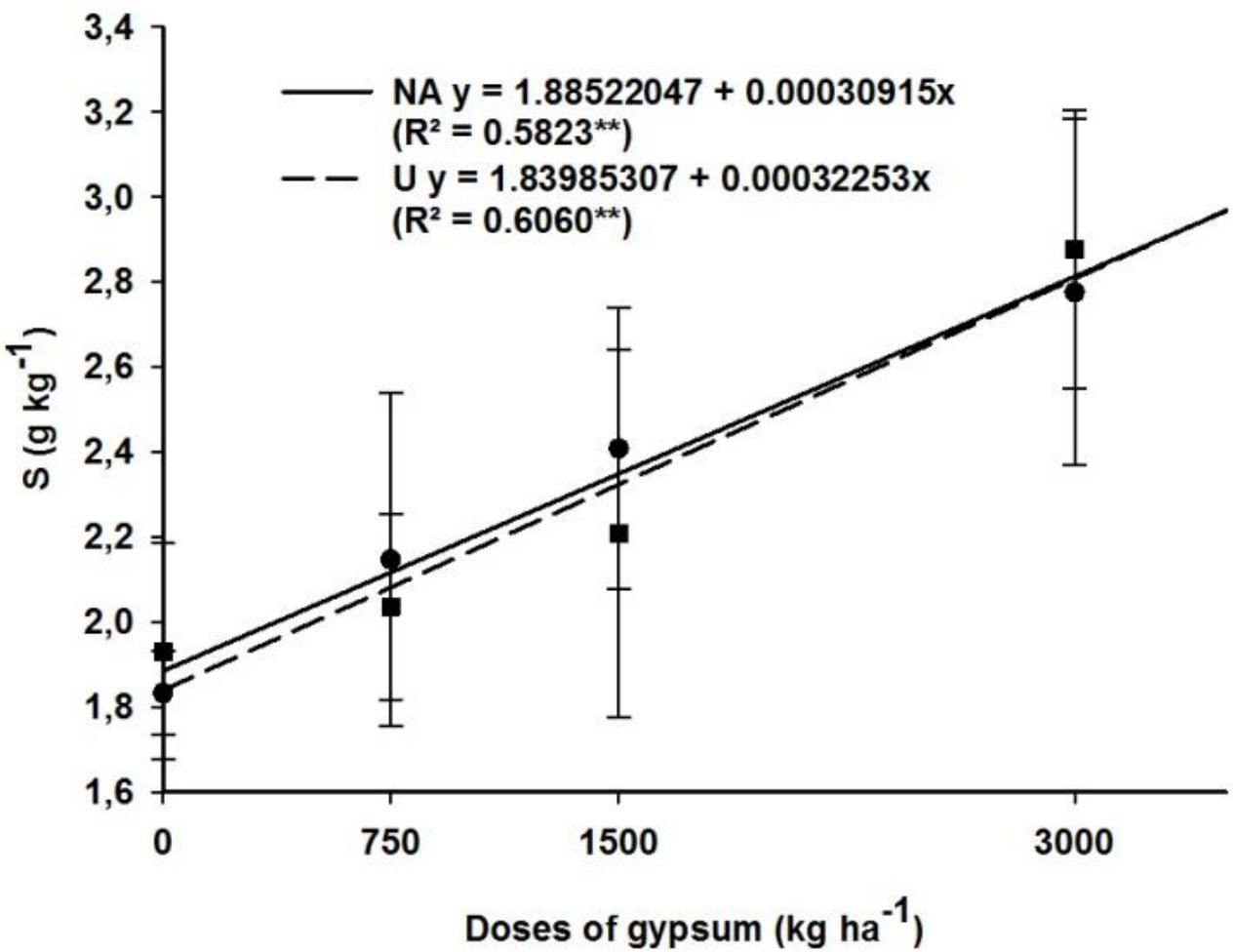

Figure 8. Regressions of nutrient $\mathrm{S}$ in $U$. humidicola as a function of $\mathrm{N}$ sources and with the application of agricultural gypsum. Andradina, 2019. $\mathrm{NA}=$ Ammonium Nitrate and $\mathrm{U}=$ Urea. Ns $\mathrm{p}=0.05$; * $0.01=<\mathrm{p}<0.05 ; * * \mathrm{p}<0.01$

Results confirm the need to supply $\mathrm{S}$ by applying gypsum in association with $\mathrm{N}$, as exposed by Guedes et al. (2000), when comparing gypsum doses on the availability of $\mathrm{N}$ and $\mathrm{S}$ in the dry matter of $U$ decumbens, it was observed that nutrients levels increased when the dose of $1,500 \mathrm{~kg} \mathrm{ha}^{-1}$ of gypsum was used. However, the nutritional status of the plants includes the good development of the bovine diet. Joris et al. (2016) explain that the improvement of the sulfate content in the soil profile is extremely important to maintain the productivity of grass crops, especially under conditions of water deficit.

The action of gypsum on the subsurface comprises an increase in $\mathrm{pH}$ promoting the predominance of negative electrical charges, which favor the movement of $\mathrm{S}_{-} \mathrm{SO}_{4}{ }^{2-}$, ensuring the permanence of adequate sulfur levels for the bovine diet, which according to NRC (1984), comprises 0.08 to $0.15 \%$ of the dry matter available.

\section{CONCLUSION}

The dose of $1,884 \mathrm{~kg} \mathrm{ha}^{-1}$ of gypsum provided the highest concentration of calcium when applied together with ammonium nitrate.

For sulfur, a linear response to gypsum doses was observed regardless of the nitrogen source used.

The use of urea significantly increased the nitrogen of the leaf.

The application of gypsum, regardless of the nitrogen source, represented a linear response in calcium and sulfur levels in the leaves.

\section{REFERENCES}

Backes, C.C.; Santos, A.J.M.; Bessa, S.V.; Ribon, A.A.; Teodoro, A.G.; Rodrigues, L.M.; Tomazelo, D.A.; Leite, L.L.F. (2018). Green coverage rate and exportation of macronutrients by Marandu grass in function of phosphogypsum application. Archivos de Zootecnia, 67: 258-235. In portuguese https://doi.org/10.21071/az.v67i258.3659 
Banzatto, D.A.; Kronka, S.N. (2013). Experimentação Agrícola. 4.ed. Funep, 237p.

Caires, E.F.; Maschietto, E.H.G.; Garbuio, F.J.; Churka, S.; Joris, H.A.W. (2011). Surface application of gypsum in low acidic Oxisoil under no-till cropping system. Scientia Agricola, 68: 4553. https://doi.org/10.1590/S0103-

90162011000200011

Caires, E.F.; Kusman, M.T.; Barth, G.; Garbuio, F. J.; Padilha, J.M. (2004). Changes in soil chemical properties and corn response to lime and gypsum applications. Revista Brasileira de Ciência do Solo, 28, 125-136. In portuguese https://doi.org/10.1590/S0100-06832004000100013

Cantarella, H.; Montezano, Z.F. (2010). 'Nitrogênio e enxofre'. In: Proch-Now, L.I.; Casarin, V.; Stipp, S.R. (Eds.), Boas práticas para uso eficiente de fertilizantes: Nutrientes, IPNI, Piracicaba, São Paulo, Brasil, p.1-65.

Costa, N.L.; Paulino, V.T.; Magalhães, J.A.; Rodrigues, B.H.N.; Santos, F.J.S. (2016). Nitrogen use efficiency, forage yield and morphogenesis of massai grass under fertilization. Nucleus, 13(2): 173-182. In portuguese http://dx.doi.org/10.3738/1982.2278.1695

Embrapa - Empresa Brasileira de Pesquisa Agropecuária. (2013). Sistema brasileiro de classificação de solos. 3.ed. Brasília, 353p.

Galindo, F.S.; Buzetti, S., Teixeira Filho, M.C.M.; Dupas, E.; Carvalho, F.D.C. (2018). Nitrogen management in mombasa guineagrass as a function of sources and rates of nitrogen. Revista de Ciências Agrárias, 41(4): 31-40. http://dx.doi.org/10.19084/RCA18131

Germano, L.H.E.; Vendruscolo, M.C.; Daniel, D.F.; Dalbianco, A.B. (2018). Productivity and agronomic characteristics of Brachiaria brizantha cv. Paiaguás exposed to different nitrogen doses under cutting. Boletim de Indústria Animal, 75: 1-14. In portuguese

https://doi.org/10.17523/bia.2018.v75.e1419

Guedes, L.M.; Graça, D.S.; Morais, M.G.; Antunes, R.C.; Gonçalves, L.C. (2000). Influence of calcium sulphate fertilization on dry matter yield, nitrogen/sulfur relation and sulphur, copper, nitrogen and nitrate concentrations in Brachiaria decumbens Stapf. Arquivo Brasileiro de Medicina Veterinária e Zootecnia, 52(5): 521-526. In portuguese http://dx.doi.org/10.1590/s010209352000000500019

Heinrichs, R.; Grano, F.G.; Bueno, L.G.F.; Soares Filho, C.V.; Fagundes, J.L.; Rebonatti, M.D.; Oliveira, K. (2013). Brachiaria sp yield and nutrient contents after nitrogen and sulphur fertilization. Revista Brasileira de Ciência do Solo, 37(4): 997-1003. http://dx.doi.org/10.1590/s010006832013000400017

Joris, H.A.W.; Caires, E.F.; Scharr, D.A.; Bini, A.R.; Haliski, A. (2016). Liming in the conversion from degraded pastureland to a no-till cropping system in Southern Brazil. Soil And Tillage Research, 162: 68-77.

http://dx.doi.org/10.1016/j.still.2016.04.009

Lacerda, J.J.J.; Resende, Á.V.; Furtini Neto, A.E.; Hickmann, C.; Conceição, O.P. (2015). Adubação, produtividade e rentabilidade da rotação entre soja e milho em solo com fertilidade construída. Pesquisa Agropecuária Brasileira, 50(9): 769-778. http://dx.doi.org/10.1590/s0100-

$204 \times 2015000900005$

Lopes, A.S.; Guimarães, L.R.G. (2016). Career Perspective on Soil Management in the Cerrado Region of Brazil. Advances In Agronomy, 137: 172. http://dx.doi.org/10.1016/bs.agron.2015.12.004

Lupatini, G.C.; Restle, J.; Vaz, R.Z.; Valente, A.V.; Roso, C.; Vaz, F.N. (2013). Beef cattle production on black oats and italian ryegrass pasture under nitrogen fertilization. Ciência Animal Brasileira, 14(2): 164-171. In portuguese http://dx.doi.org/10.5216/cab.v14i2.21068

Malavolta, E. (1981). Manual de Química Agrícola Adubos e Adubação. 3. ed. São Paulo: Ceres Ltda, $596 \mathrm{p}$.

Malavolta, E.; Vitti, G.C.; Oliveira, S.A. (1997). Avaliação do estado nutricional das plantas: princípios e aplicações. Piracicaba: Potafos, 319p. 
Mérigout, P.; Gaudon, V.; Quilleré, I.; Briand, X.; Daniel-Vedele, F. (2008). Urea Use Efficiency of Hydroponically Grown Maize and Wheat. Journal Of Plant Nutrition, 31(3): 427-443. http://dx.doi.org/10.1080/01904160801894970

Mesquita, E.E.; Fonseca, D.M.; Pinto, J.C.; Nascimento Junior, D.; Preira, O.G.; Venegas, C.H.A.; Moreira, L.M. (2004). Establishment of mixed pasture with application of limestone, gypsum and phosphorus. Ciência e Agrotecnologia, 28(2): 428-436. In portuguese http://dx.doi.org/10.1590/s1413-

70542004000200025

Nava, G.; Ernani, P.R.; Sá, A.A.; Pereira, A.J. (2012). Soil composition and nutritional status of apple as affected by long-term application of gypsum. Revista Brasileira de Ciência do Solo, 36(1): 215-222. http://dx.doi.org/10.1590/s010006832012000100022

Nogueira, K.B.; Roque, C.G.; Borges, M.C.R.Z.; Troleis, M.J.B.; Barreto, R.F.; Oliveira, M.P. (2016). Atributos físicos do solo e matéria orgânica sob dois manejos e efeito residual da aplicação de calcário e gesso agrícola. Revista de la Facultad de Agronomía, 115(1): 45-54 2016.

NRC - National Reserch Concil. (1984). Committee on animal nutrition. Nutrient requeriments of beef cattle. 6.ed. Washington: National Academy of Sciences, 90p.

Pauletti, V.; Pierri, L.; Ranzan, T.; Barth, G.; Motta, A.C.V. (2014). Efeitos em longo prazo da aplicação de gesso e calcário no sistema de plantio direto. Revista Brasileira de Ciência do Solo, 38(2): $\quad$ 495-505.http://dx.doi.org/10.1590/s010006832014000200014

Pezzopane, C.G.; S antos, P.M.; Cruz, P.G.; Altoé, J.; Ribeiro, F.A.; Valle, C.B. (2015). Hydric deficiency in genotypes of Brachiaria brizantha. Ciência Rural, 45(5): 871-876. In portugese http://dx.doi.org/10.1590/0103$8478 \mathrm{cr} 20130915$

R CORE TEAM. R: A language and environment for statistical computing. RStudio. R Foundation for Statistical Computing, Vienna, Austria. (2015). URL: https://www.R-project.org/

Raij, B.; Andrade, J.C.; Cantarella, H.; Quaggio, J.A. (2001). Análise química para avaliação da fertilidade de solos tropicais. Campinas: Instituto Agronômico, 285p.

Raij, B.; Cantarella,H.; Quaggio, J.A.; Furlani, A.M.C. (1996) Recomendações de adubação e calagem para o Estado de São Paulo. 2.ed. Campinas: IAC, 285p.

Silva, J.L.; Ribeiro, K.G.; Herculano, B.N.; Pereira, O.G.; Pereira, R.C.; Soares, L.F.P. (2016). Dry matter production and structural and bromatological characteristics of Brachiaria and Panicum cultivars. Ciência Animal Brasileira, 17(3): 342348. http://dx.doi.org/10.1590/10896891v17i332914

Sousa, D.M.G.; Nunes, R.S.; Rein, T.A.; Santos Junior, J.D.G.; Oliveira, S.A. (2016). 'Acidez do solo e sua correção na região do cerrado'. In: Flores, R.A.; Cunha, P.P. (eds.), Práticas de Manejo do Solo para Adequada Nutrição de Plantas no Cerrado. Gráfica UFG, Goiânia, Goiás, Brasil. cap.5, p.124-190.

Taiz, L.; Zeiger, E.; Moller, I.; Murphy, A. (2017). Fisiologia e desenvolvimento vegetal. 6.ed. Porto Alegre: Artmed, 888 p.

Yamamoto, C.J.T.; Gasparim, M.B.; Machado Neto, N.B.M.; Custodio, C.C. (2018). Early Seedling Growth as a Tool to Assess the Tolerance of Urochloa brizantha Cultivars to Free Aluminium. Journal of Agricultural Science 